\title{
Challenges Faced by Teachers in Remote Area During Pandemic Covid-19
}

\author{
Putu Rahayu Ujianti
}

\author{
Universitas Pendidikan Ganesha, Bali, Indonesia \\ Corresponding author. Email: puturahayuujianti@undiksha.ac.id
}

\begin{abstract}
Covid-19 pandemic forces the schools to close and the students learn from home. Online learning becomes one of the consequences. However, not all teachers and students are able to implement online learning because of several factors. This phenomenon is experienced by the front-line Indonesian teachers who teach in the remote area, or in Bahasa Indonesia namely "Terdepan, Terluar, dan Tertinggal (3T)". The aim of this study is to investigate the practice of teaching and learning in remote areas and challenges the front-line teachers face in this pandemic situation. The study used qualitative data analysis using an interactive model which included data collection and data reduction, display data, and draw and verify the conclusion. The results show the biggest challenges for front-line teachers are the limited telecommunication equipment on the part of the students, and a stable network, and the cost of the internet as it is not a free service. Other challenges are the students' low discipline and motivation in completing the assignments, lack of their attendance when the teachers visited their homes, and the lack of support from parents and government.
\end{abstract}

Keywords: Covid-19, online learning, front line teachers, online learning at the remote area.

\section{INTRODUCTION}

The Covid-19 pandemic has changed a lot of things, especially in the education sector [1], [2], [3], [4], [5], [6], [7], [8]. Previously, learning activities were centered in schools. Today, direct face to face activities in schools are limited and most educational activities are conducted online.

Closing schools physically and replacing them with learning at/from home has changed the teaching and learning system [9]. School managers, students, parents, and teachers must migrate to digital or online learning systems, which is broadly known as e-learning [10], [11], [12] or known as online learning or "pembelajaran daring" in Indonesian.

So far, the study of the online learning system in the Covid-19 era focused on two trends [13]. Firstly, it focuses on researching the online learning implementation [14]. [15], [16], [17], [18], [19]. Secondly, it investigates the problems or the impacts of the policy of online learning implementation [20], [21]. Yudiawan adds that evaluation in the implementation of online learning has not been carried out comprehensively in both of these research trends [13]. Most of all, evaluation is important in every implementation of activities or programs to ensure the objectives are in line with standards [22].
This research aims at complementing the literature about evaluation and online learning implementation, especially in remote areas which creates certain challenges for the teachers there. The Indonesian 3T schools are struggling in their learning activities and face a lot of obstacles. The most important one is the limited communication and internet access which becomes the biggest struggle for the remote area teachers.

The main problem in the $3 \mathrm{~T}$ area besides the lack of access to education, is also facing a lack of teachers. Since 2015, 7093 teachers have been sent to the front lines of the country to equalize the quality of education. 7093 teachers are spread across 93 districts, which in their territory include the frontier, outermost, and isolated areas (www.indonesiabaik.id). Before the pandemic, teaching in 3T areas had become a challenge for teachers because the access to schools is far and difficult, with damaged and unpaved roads and far from the economic center. During the pandemic, the difficulty increases because in carrying out online learning, the teacher must keep thinking of ways to make learning materials available to students while the access to telecommunication and the internet is very limited. Although the government provides concessions through simplifying the learning design and emergency curriculum, teachers are still required to complete teaching materials on time and meet the predetermined learning outcomes. 


\section{METHOD}

The research uses descriptive qualitative design. The purpose of this research is to describe the challenges faced by teachers in the $3 \mathrm{~T}$ areas in implementing the learning activities during the Covid-19 pandemic. The learning here means all types of learning activities including online learning (daring), offline learning (luring), and blended learning. The respondents of this research were the front-line teachers or in Indonesian called "Guru Garis Depan" who teach in the primary and secondary schools at remote areas.

The research was firstly conducted by distributing questionnaires through google form to the respondents. The 3 respondents out of 20 respondents then were being deeply interviewed through a phone call. The selection of respondents was based on the representation of the types of learning carried out during the Covid-19 pandemic, which are online, offline, and blended. The main difficulty in capturing respondents was the telecommunications access to reach and contact the teachers who work in the $3 \mathrm{~T}$ areas. Data were collected from September to October 2020. Respondents were scattered in 3T areas in the Provinces of East Java, Papua, and East Nusa Tenggara.

Several aspects were explored through the interviews: (1) types of learning practices during the pandemic; (2) obstacles and challenges faced by teachers; and (3) support and assistance received by teachers.

The analysis of research data was carried out using the analysis model of Miles \& Huberman which consists of three stages, namely data reduction, data display, and conclusion drawing and verification [23].

\section{RESULT AND DISCUSSION}

The challenges faced by the $3 \mathrm{~T}$ areas teachers in carrying out online learning during Covid-19 are:

\subsection{Online Learning is Very Difficult to Implement}

Despite the government policy about learning implementation during Covid-19, the schools in 3T areas are closed and the front-line teachers must teach through online-based learning. Yet, in reality, this is difficult to implement in $3 \mathrm{~T}$ areas. From the 20 respondents, thirteen said they faced no option but implemented the face-toface learning through home visits, three teachers implement offline learning at schools, and four others try to combine online and offline learning at schools. None of the 20 respondents are doing fully online learning. Mulyasa states that the role of teachers is not only conveying information to the students, but also able to be the facilitator that focuses on facilitating the learning process, thus, the students can learn in the class atmosphere of fun, happiness, full of enthusiasm, not anxious, and able to express opinions openly [24]. Thus, what is meant by a facilitator is that the teacher must prepare himself in any situation, including the current pandemic state. If there are students who cannot participate in classroom learning and are required to learn online, the teacher must be able to facilitate this online learning demand. If students cannot go online, one example is that teachers can come to students at home or vice versa; students can come to the teacher's house [25].

\subsection{Limited Communication and Internet Access}

The main thing that becomes the biggest struggle in the $3 \mathrm{~T}$ area online learning implementation is the limited communication and network devices, both telephone and internet signals. The internet is difficult to access, where it is only reachable in certain spots because of the hilly landscape. On the other hand, some of the places still have no continued electricity services. The electricity is only available in some hours and even blackouts in most of the hours. It is difficult to access the alternative learning facilities from the Ministry of Education or Kementerian Pendidikan dan Kebudayaan through educational television channels. The limited economic condition of the parents also becomes the struggle of the students. They cannot afford a cellphone, computer, or laptop to be used as a learning tool. Even they rarely have money to buy the internet. Problems related to the limited telecommunications devices, difficult and unstable internet network access due to geographical conditions, and the inability to purchase internet implement online learning becomes less effective [26].

\subsection{Limited Road Access}

Because the schools are mostly closed, while telephone and internet networks are limited, teachers are doing home visits to students' houses. Some visit once a week, some up to three times a week depending on the number of students. The challenge with this home visit is that the students' houses are far apart and difficult to reach due to the hilly geographical and the damaged and unpaved roads. To work around this, the teacher borrows people's houses to be used as learning posts. This learning post is a gathering point for several students whose houses are around the post. Within a day, the teacher will tour several learning posts.

The concern of teachers is in those who are forced to do face-to-face learning in schools. The distance from students' houses that are difficult to reach for home visits has made schools reopen themselves in several areas with various restrictions. Those are the restrictions on the number of students and the number of meetings only once a week for each class. However, respondents who conducted face-to-face learning at school express a lot of 
concerns because students often neglect health protocols and are not used to wearing masks.

\subsection{Students' Learning Motivation and Discipline}

The students' learning motivation and discipline become a certain problem for the teachers. Students perceive the pandemic as the holiday time which makes them have no motivation in attending the learning activities. The students are often not at home even though they know the teachers will have a home visit that day. Sobon emphasizes that in learning, motivation is one important factor that influences the efficiency of the learning activity because motivation pushes the students in doing learning activity [27]. Learning motivation also means the overall driving force from within the student which boosts the learning activities that are manifested in the form of the need, encouragement, and effort of students in carrying out activities to achieve goals.

\subsection{The Lack of Parental Participation in Assisting the Students to Learn}

Ideally, when the students are mostly at home, then the parents are expected to assist their learning activities. In reality, as the impact of the lack of education, the parents in 3T areas cannot do their role properly. Based on the data obtained, several students were expected to help on the farm or to attend traditional events with their parents and so they were unavailable during home visit. Parents also have to work and take care of the house, so that communication occurs only in one direction, teachers send assignments, parents send children's work, without supervision in learning [28].

\subsection{Government Support}

Up until October of 2020, only two out of twenty respondents said they received support in the form of real assistance from the government or related agencies. One respondent stated that he received support in the form of emergency curriculum socialization, training on making learning videos, and training making quizzes using google form. One other respondent stated that he received assistance in the form of BDR (learning from home) transportation money and internet access. Unfortunately, both the internet and training in making learning videos or making quizzes using a google form to support online learning cannot be used due to the lack of an internet network. There was also internet credit allowance for students, but it cannot be used because students do not have cell phones.

\section{CONCLUSION}

Online learning is the answer to the implementation of government policies on learning at/from home during pandemic. However, due to the uneven development of telecommunications infrastructure in Indonesia, geographical conditions, and the minimal economic capacity of parents, it becomes a real challenge for teachers in the $3 \mathrm{~T}$ areas in implementing online-based learning. Therefore, if special efforts are not made such as home visits and reopening the schools with health protocol rules, students' access to teaching and learning materials will be very limited. This even becomes the real potential of the virus to be spread which actually had been tried to be prevented through learning from/at home policy. Therefore, the basic thing that is urgent to be resolved by the government is the problem of telecommunications infrastructure and the provision of supporting telecommunications devices that support the implementation of online learning. The true success of education cannot be separated from other factors, such as political and economic policies. The policies should be mandatory to be right on target, not like in this case, giving internet allowance while there is no internet signal in the students' area.

\section{REFERENCES}

[1] Anderson J. Should Schools Close When Coronavirus Cases Are Still Rare? Quartz [internet]. 2020 March 4. Available from: https://finance.yahoo.com/news/schools-closecoronavirus-cases-still-090027702.html.

[2] Azzi-Huck K, Shmis T. Managing The impact of COVID-19 on Education Systems Around the World: How Countries Are Preparing, Coping, And Planning for Recovery. World Bank Blogs [internet]. 2020 March 18. Available from: https://blogs.worldbank.org/education/managingimpact-covid-19-education-systems-around-worldhow-countries-are-preparing.

[3] Horn MB. COVID-19's Long-Term Impacts on Education in 2020 and Beyond. EdSurge [internet]. 2020 March 23. Available from: https://www.edsurge.com/news/2020-03-23-covid19-s-long-term-impacts-on-education-in-2020-andbeyond.

[4] Huang RH, Liu DJ, Tlili A, Yang JF, Wang HH. Handbook on Facilitating Flexible Learning During Educational Disruption: The Chinese Experience in Maintaining Undisrupted Learning in COVID-19 Outbreak [internet]. Beijing: Smart Learning Institute of Beijing Normal University; 2020 March. Available from: https://iite.unesco.org/wpcontent/uploads/2020/03/Handbook-on-FacilitatingFlexible-Learning-in-COVID-19-OutbreakSLIBNU_V2.0_20200324.pdf.

[5] ALSDE. Novel Coronavirus (COVID-19) in K-12 Schools: A parent guide [internet]. Montgomery: The Alabama State Department of Education; 2020 March 12. Available from: 
https://www.sccboe.org/site/handlers/filedownload. ash $x$ ? moduleinstanceid $=7858 \&$ dataid $=8783 \&$ FileN ame $=$ CORONA_PARENTGUIDE.pdf.

[6] van Fleet J. Education in the time of COVID-19. Global Partnership for Education [internet]. 2020 March $18 . \quad$ Available from: https://www.globalpartnership.org/blog/educationtime-covid-19.

[7] World Health Organization. Key messages and actions for COVID-19 prevention and control in schools. 2020. Available from: https://www.who.int/docs/default-

source/coronaviruse/key-messages-and-actions-forcovid-19-prevention-and-control-in-schools-march2020.pdf.

[8] Yan W. How will COVID-19 impact global education. China Daily [internet]. 2020 March 17. Available from: http://www.chinadaily.com.cn/a/ 202003/17/WS5e7045e9a31012821727fb8b.html.

[9] Arora AK, Srinivasan R. Impact of pandemic COVID-19 on the teaching-learning process: A study of higher education teachers. Prabandhan: Indian Journal of Management. 2020 Apr 30;13(4):43-56.

[10] Jordan C. Coronavirus outbreak shining an even brighter light on internet disparities in rural America. Washington, DC: The Hill; 2020.

[11]Karp, P., \& McGowan, M. “Clear as mud” Schools ask for online learning help as Coronavirus policy confusion persists. The Guardian. 2020 March 23. Available from: https://www.theguardian.com/ australia-news/2020/mar/24/clear-as-mud-schoolsask-for-online-learning-help-as-coronavirus-policyconfusion-persists.

[12] UNESCO. Distance learning solutions. UNESCO's COVID-19 Education Response [internet]. 2020. Available from: https://en.unesco.org/covid19/ educationresponse/solutions

[13] Yudiawan A. Belajar bersama COVID 19: Evaluasi pembelajaran daring era pandemi di perguruan tinggi keagamaan Islam negeri, Papua Barat. AL-FIKR: Jurnal Pendidikan Islam. 2020 Aug 1;6(1):10-6.

[14] Anhusadar L. Persepsi mahasiswa PIAUD terhadap kuliah online di masa pandemi Covid 19. KINDERGARTEN: Journal of Islamic Early Childhood Education. 2020 Apr 29;3(1):44-58.

[15] Elyana L. Manajemen parenting class melalui media e-learning. Sentra Cendekia. 2020 May 17;1(1):2935.

[16] Susilo AT, Hartanto AP. Academic burnout pada peserta didik terdampak pandemi covid-19. GCouns: Jurnal Bimbingan dan Konseling. 2020 Dec 31;5(1):123-30.
[17] Suyono S. Manajemen pembelajaran berbasis daring dalam rangka memutus mata rantai penularan covid19 di perguruan tinggi swasta lembaga layanan perguruan tinggi (llDikti) wilayah VII. EdHumanistics: Jurnal Ilmu Pendidikan. 2020;5(1):662-6.

[18] Gunawan G, Suranti NM, Fathoroni F. Variations of models and learning platforms for prospective teachers during the COVID-19 pandemic period. Indonesian Journal of Teacher Education. 2020 Apr $25 ; 1(2): 61-70$

[19]Firman F, Rahayu S. Pembelajaran online di tengah pandemi covid-19. Indonesian Journal of Educational Science (IJES). 2020 Apr 27;2(2):81-9.

[20]Latip A. Peran literasi teknologi informasi dan komunikasi pada pembelajaran jarak jauh di masa pandemi Covid-19. EduTeach: Jurnal Edukasi dan Teknologi Pembelajaran. 2020 Jun 1;1(2):108-16.

[21] Windhiyana E. Dampak Covid-19 terhadap kegiatan pembelajaran online di sebuah perguruan tinggi kristen di Indonesia. Perspektif Ilmu Pendidikan. 2020 Apr 29;34(1):1-8.

[22] Gronlund NE, Robert LL. Educational Assessment and Reporting. San Diego: Harcourt Brace Javanovich; 1991.

[23] Miles MB, Huberman, M. Qualitative Data Analysis Second Edition. London: SAGE Publications; 1994.

[24] Mulyasa E. Teacher's Competency Standard and Certification. Bandung: PT Remaja Rosdakarya; 2003.

[25] Sukitman, T., Yazid, A., Mas'odi. Teacher role during pandemic Covid. Proceeding National Thematic Discussion 2020 "Education During Pandemic": Study from Regions. 2020 September 5.

[26] Ministry of Education and Culture Republic Indonesia. Letter No. 4/2020 about the implementation of education policies in the emergency period of CoronaVirus disease (Covid19).

[27] Sobon K, Mangundap JM, Walewangko S. Pengaruh Penggunaan Smartphone Terhadap Motivasi Belajar Siswa Sekolah Dasar di Kecamatan Mapanget Kota Manado. Autentik: Jurnal Pengembangan Pendidikan Dasar. 2019;3(2):97-106.

[28]Rigianti HA. Kendala Pembelajaran Daring Guru Sekolah Dasar Di Banjarnegara. Elementary School: Jurnal Pendidikan dan Pembelajaran ke-SD-an. 2020 Jul 1;7(2): 297-302. 